\title{
Growth Response of Leucaena Embryogenic Callus on Embryo Age Differences and Auxin 2,4-Dichlorophenoxyacetic Acid
}

\author{
Manpaki SJ ${ }^{1}$, Prihantoro I ${ }^{2}$, Karti, $\mathrm{PDMH}^{2}$ \\ ${ }^{I}$ Graduate School of Nutrition and Feed Science, Bogor Agricultural University, Bogor 16680, Indonesia \\ ${ }^{2}$ Department of Nutrition and Feed Technology, Faculty of Animal Science, Bogor Agricultural University, Bogor 16680, Indonesia \\ E-mail: satriajulier83@gmail.com
}

(received 26-03-2018; revised 22-05-2018; accepted 23-06-2018)

\begin{abstract}
ABSTRAK
Manpaki SJ, Prihantoro I, Karti PDMH. 2018. Respon pertumbuhan kalus embriogenik tanaman lamtoro terhadap perbedaan umur embrio dan hormon Auksin 2,4-Dichlorophenoxyacetic acid. JITV 23(2): 95-102. DOI: http://dx.doi.org/10.14334/jitv.v23i2.1538

Lamtoro (Leucaena leucocephala cv. Tarramba) merupakan hijauan sumber protein dari famili leguminosa. Varietas Tarramba mampu beradaptasi dengan baik di daerah tropis dan kering yaitu Nusa Tenggara Barat dan Nusa Tenggara Timur. Penelitian ini bertujuan untuk mengidentifikasi respon pertumbuhan dan morfologi kalus embriogenik tanaman lamtoro $(L$. leucaena $\mathrm{cv}$. Tarramba) terhadap umur embrio yang berbeda dan level pemberian zat pengatur tumbuh auksin 2.4-D. eksplan yang digunakan berasal dari tanaman lamtoro (L. leucaena cv. Tarramba) sebanyak 400 eksplan. Penelitian ini terdiri dari 16 perlakuan dengan dua faktor, faktor pertama adalah pemberian konsentrasi ZPT 2,4-D $0.5 \mathrm{mg} / \mathrm{L}, 1 \mathrm{mg} / \mathrm{L}, 1.5 \mathrm{mg} / \mathrm{L}, \mathrm{dan} 2 \mathrm{mg} / \mathrm{L}$. Faktor kedua adalah jenis embrio mature embryo, cotyledon, heart, dan pre-globular. Masing-masing perlakuan diulang sebanyak 25 ulangan. Penelitian ini menggunakan rancangan lingkungan acak lengkap (RAL) dua faktor dengan analisis ragam (ANOVA). Penelitian ini diuji lanjut menggunakan Duncan. Analisis ragam menunjukkan pemberian ZPT 2,4-D pada konsentrasi $1.5 \mathrm{mg} / \mathrm{L}$ dan jenis mature embryo terhadap parameter pertambahan tinggi kalus, pertambahan diameter kalus, dan skor warna kalus berbeda nyata $(\mathrm{P}<0.05)$. parameter tekstur kalus menunjukkan hasil yang seragam pada seluruh perlakuan yaitu kompak. Kalus embriogenik tanaman lamtoro (Leucaena leucocephala cv. Tarramba) menunjukkan respon yang optimal pada konsentrasi ZPT 2,4-D $1.5 \mathrm{mg} / \mathrm{L}$ dan jenis mature embryo.
\end{abstract}

Kata Kunci: Auksin 2,4-D, Embrio, Embriogenik, Kalus, Lamtoro cv. Tarramba

\section{ABSTRACT}

Manpaki SJ, Prihantoro I, Karti PDMH. 2018. Growth response of leucaena embryogenic callus on embryo age differences and Auxin 2,4-Dichlorophenoxyacetic acid. JITV 23(2): 95-102. DOI: http://dx.doi.org/10.14334/jitv.v23i2.1538

Leucaena (Leucaena leucocephala cv. Tarramba) is a source of protein from the legume family. Tarramba varieties able to adapt well in tropical area such as West Nusa Tenggara and East Nusa Tenggara. This study aimed to identify the growth response and embryogenic callus morphology of lamtoro (L. leucaena cv. Tarramba) in embryos different ages and auxin 2,4-D levels. This research was used explants derived from lamtoro (L. leucocephala cv. Tarramba) as much 400 explants. this study conducted of 16 treatments with two factors, the first factor is the provision of PGR 2,4-D concentration of $0.5 \mathrm{mg} / \mathrm{L}, 1 \mathrm{mg} / \mathrm{L}$, $1.5 \mathrm{mg} / \mathrm{L}$ and $2 \mathrm{mg} / \mathrm{L}$. The second factor was the type of embryo such as mature embryo, cotyledon, heart, and pre-globular. Each treatment was repeated 25 replications. This study uses a randomized complete design (CRD) with two factors. Data were analyzed using analysis of variance and if there was significant difference, data were further analyzed using Duncan's multiple range test. Analysis of variance showed that PGR 2,4-D at a concentration of $1.5 \mathrm{mg} / \mathrm{L}$ and the type of optimum embryo was mature embryo callus on parameters as height, diameter increment callus, and callus color scores were significantly different $(\mathrm{P}<0.05)$. callus texture parameter indicates results that are uniform throughout the treatment that was compact callus. Lamtoro plant embryogenic callus (L. leucocephala cv. Tarramba) indicate an optimal response at the concentration of PGR 2,4-D 1.5 $\mathrm{mg} / \mathrm{L}$ and the type of embryo was mature embryo.

Key Words: Auxin 2,4-D, Embryo, Embryogenic, Callus, Lamtoro cv. Tarramba

\section{INTRODUCTION}

Forage is the main source of ruminants feed. Forage play an important role in basic needs of cattles living, growth, power source, as well as an important component in supporting the production and reproduction of livestock. The forage requirement for ruminants is still relatively high, but the quality of productivity in the tropics is still relatively low. In general, forages are divided into two large families, Graminae and Leguminouse. Legume family is a source of protein. One type of legume that has a relatively high 
crude protein and is known well by the breeder is Leucaena (Leucaena leucocephala). Lamtoro plant has crude protein content of $23.7 \%$ - 34\% and has a high palatability (Yumiarty \& Suradi 2010).

Lamtoro plants can adapt well in the tropics. Additionally, lamtoro able to adapt to the soil with moderate acidity between $\mathrm{pH} 5.5-6.5$ and temperate climate with an annual rainfall of over $760 \mathrm{~mm}$ in the region of East Nusa Tenggara and West Nusa Tenggara. One lamtoro varieties that are well developed in Indonesia is Tarramba varieties. Based on research of Yumiarty \& Suradi (2010) lamtoro varieties Tarramba (Leucaena leucocephala cv. Tarramba) has the advantage of a leafhopper resistant to pests and resistant to drought. Manpaki et al. (2016) states lamtoro Tarramba varieties are grown through somatic phase lasting at $\mathrm{pH}$ 5.5. Utilization of tissue culture technology enables to perform fast and accurate assessment. Furthermore, tissue culture techniques allow for the rapid multiplication of seeds produced, uniform quality, and facilitate the standardization of plant seeds.

Provision of plant parts such candidates protoplasm, the cell, group of cells, tissues and organs can be performed with tissue culture methods that will produce meristematic or embryogenic sections. Culture of lamtoro is efficient and allows to get a diversity of genetic variation is a callus. Callus is an organized collection of cells comprising paranchyma cells. Selected candidates callus is embryogenic explants. Selection of embryogenic explants to produce derivative irreversible means superior properties of genetic diversity decrypted result is not returned to normal.

Mechanism of callus growing derived from the embryo plant varieties Tarramba lamtoro done carefully because the span of embryo growth can not be ensured in practice. Growing young embryos performed at optimal environmental in vitro condition. Techniques using embryonic explants derived from plants have been used to obtain seeds from the crosses between species of plants. The major advantage in using callus explant embriogenic is able to accelerate the acquisition of callus as used are very young embryos, so the development of the callus is not rapidly decreasing and potentially extend the life of callus in a long time. The use of increasingly younger explants will improve in vitro culture. Age significantly affected the development of the embryo to corn embryo explants in vitro (Binott et al. 2008).

The development of biotechnology through forage breeding through tissue culture can be carried out with the help of plant growth regulator (PGR). Plant growth regulators is one important factor in the successful growth of callus cultured. In general, plant growth regulators can be divided into two plant growth regulators or phytohormones called endogenous and exogenous growth regulating substances or synthetic. Plant growth regulators on the plant consists of five groups: auxin, cytokinin, gibberellin, ethylene and abscisic acid. In the development of callus, auxin hormones from the class provides the greatest impact. Auxin is a compound effect on cell growth, raising the osmotic pressure, increase protein synthesis, increase the cell permeability to water and flex or soften the cell walls that followed reduced pressure cell wall so that water can get into the cell, along with the increase in cell volume. Therefore, in plant growth regulator substances have a significant influence in explants growth. Auxin used in this study was 2.4Dichlorophenoxyacetic acid (2,4-D) as a synthetic hormone that is more stable and not easily decomposed by changes in temperature and enzymatic.

Forage breeding using tissue culture techniques is expected to give good results for growth, as well as the properties of uniform and superior in plant embryogenic callus lamtoro Tarramba varieties selected at the level of plant growth regulator auxin 2.4-D. This study aims to identify of growth response and embryogenic callus morphology of plants lamtoro (L. leucaena cv. Tarramba) of the embryos different ages and levels of growth regulator auxin giving 2.4-D.

\section{MATERIALS AND METHODS}

This research was conducted at the laboratory of Plant Biotechnology, Feed Science and Technology Department, Division of Forages and Pasture, Faculty of Animal Science, Bogor Agricultural University. This research was conducted for 3 months starting in September 2016 until December 2016. The material used in this study are a lamtoro peas (L. leucocephala cv. Tarramba) different from the common garden collection, Field Laboratory of Forages and Pasture, Faculty of Animal Science, Bogor Agricultural University, materials sterilization form $70 \%$ alcohol, $96 \%$ alcohol, soap, clorox $10 \%$ to $20 \%$, distilled water, plant growth regulator auxin $(2.4 \mathrm{D})$, MS medium (Murashige and Skoog) basal, $\mathrm{AlCl}_{3}$, explant culture equipment, laminar airflow, as well as observation equipment parameters.

This study consisted of two phases of research, there are preparation of explants embryos and embryonic callus induction on media treatment. Explants embryos to be used is derived from plant pods lamtoro ( $L$. leucocephala cv. Tarramba) of different ages. Lamtoro pods thoroughly washed with soap and then sterilized using 20\% Clorox for 7 minutes, then Clorox $15 \%$ for 7 minutes, and soaked in Clorox $10 \%$ for 7 minutes. After soaking, rinse the pod in distilled water for 5 minutes. Sterile pods in place in a petri dish to do the stripping. The pods are taken consisted of four age groups, 
namely pre-globular, heart, cotyledon and mature embryos.

The main media used was MS medium plus growth regulator (PGR) 2.4 dichlrophenoxyacetic acid for callus induction at a concentration of $0.5 \mathrm{mg} / \mathrm{L}, 1 \mathrm{mg} / \mathrm{L}$, $1.5 \mathrm{mg} / \mathrm{L}$, and $2 \mathrm{mg} / \mathrm{L}$. The explants used were preglobular, heart, cotyledon and mature embryos were transferred into the medium with a subculture technique in a laminar airflow. Each bottle contains $20 \mathrm{ml}$ of media were planted 1 embryos in accordance with the treatment given. Callus induction was observed for five weeks weeks. Explants grown into a green compact callus indicates the use of a good growing medium. The design environment used in the study of this phase is completely randomized design (CRD) Factorial with A factor is a given plant growth regulator and factor $\mathrm{B}$ is a type of plant embryos were used as explants. PGR used at one stage was 2.4 dichlorophenoxyacetic acid by 4 levels of treatment there are $0.5,1.0,1.5$, and $2.0 \mathrm{mg} / \mathrm{L}$. Each treatment was repeated 20 times with the unit observation in the form of a vial containing MS medium and 1 explant. Data will be analyzed using analysis of variance (ANOVA) using SPSS instrument 16 , then if there is difference will be test with Duncan test.

\section{RESULTS AND DISCUSSION}

\section{Plant height and callus diameter (L. leucocephala cv. Tarramba)}

Height and diameter of the callus is a major variable in the morphological characteristics of the plant. Height callus of lamtoro (L. leucocephala $\mathrm{cv}$. Tarramba) are presented in Table 1 .

Table 1. Height growth of embryogenic callus (L. leucocephala cv. Tarramba)

\begin{tabular}{|c|c|c|c|c|c|}
\hline \multirow{3}{*}{ PGR doses 2,4-D (mg/L) } & \multicolumn{4}{|c|}{ Embryo types } & \\
\hline & Mature embryo & Cotyledon & Heart & \multirow{2}{*}{ Pre-globular } & \\
\hline & \multicolumn{4}{|c|}{ 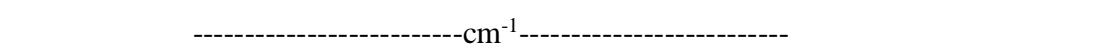 } & \\
\hline \multicolumn{6}{|l|}{$1 \mathrm{WAP}$} \\
\hline 0.5 & $0.285 \pm 0.152$ & $0.255 \pm 0.005$ & $0.088 \pm 0.004$ & $0.000 \pm 0.000$ & $0.157^{\mathrm{c}}$ \\
\hline 1 & $0.115 \pm 0.011$ & $0.255 \pm 0.114$ & $0.200 \pm 0.008$ & $0.000 \pm 0.000$ & $0.142^{\mathrm{c}}$ \\
\hline 1.5 & $1.085 \pm 0.230$ & $0.935 \pm 0.179$ & $0.595 \pm 0.022$ & $0.000 \pm 0.000$ & $0.653^{\mathrm{a}}$ \\
\hline \multirow[t]{2}{*}{2} & $0.921 \pm 0.198$ & $0.815 \pm 0.093$ & $0.535 \pm 0.018$ & $0.000 \pm 0.000$ & $0.567^{\mathrm{b}}$ \\
\hline & $0.602^{\mathrm{a}}$ & $0.565^{\mathrm{a}}$ & $0.354^{\mathrm{b}}$ & $0.000^{c}$ & \\
\hline \multicolumn{6}{|l|}{$2 \mathrm{WAP}$} \\
\hline 0.5 & $0.700 \pm 0.277$ & $0.365 \pm 0.067$ & $0.275 \pm 0.008$ & $0.000 \pm 0.000$ & $0.335^{\mathrm{b}}$ \\
\hline 1 & $0.520 \pm 0.058$ & $0.470 \pm 0.202$ & $0.235 \pm 0.098$ & $0.000 \pm 0.000$ & $0.306^{\mathrm{b}}$ \\
\hline 1.5 & $1.645 \pm 0.377$ & $1.215 \pm 0.195$ & $0.580 \pm 0.041$ & $0.000 \pm 0.000$ & $0.860^{\mathrm{a}}$ \\
\hline \multirow[t]{2}{*}{2} & $1.785 \pm 0.262$ & $0.985 \pm 0.093$ & $0.675 \pm 0.078$ & $0.000 \pm 0.000$ & $0.861^{\mathrm{a}}$ \\
\hline & $1.162^{\mathrm{a}}$ & $0.758^{b}$ & $0.441^{\mathrm{c}}$ & $0.000^{\mathrm{d}}$ & \\
\hline \multicolumn{6}{|l|}{3 WAP } \\
\hline 0.5 & $0.875 \pm 0.201$ & $0.400 \pm 0.097$ & $0.280 \pm 0.008$ & $0.000 \pm 0.000$ & $0.388^{b}$ \\
\hline 1 & $0.755 \pm 0.066$ & $0.435 \pm 0.042$ & $0.550 \pm 0.166$ & $0.000 \pm 0.000$ & $0.435^{\mathrm{b}}$ \\
\hline 1.5 & $1.705 \pm 0.640$ & $0.925 \pm 0.205$ & $0.635 \pm 0.087$ & $0.110 \pm 0.047$ & $0.843^{\mathrm{a}}$ \\
\hline \multirow[t]{2}{*}{2} & $1.790 \pm 0.120$ & $1.030 \pm 0.121$ & $0.675 \pm 0.078$ & $0.000 \pm 0.000$ & $0.873^{\mathrm{a}}$ \\
\hline & $1.281^{\mathrm{a}}$ & $0.697^{\mathrm{b}}$ & $0.535^{\mathrm{c}}$ & $0.027^{\mathrm{d}}$ & \\
\hline \multicolumn{6}{|l|}{4 WAP } \\
\hline 0.5 & $0.345 \pm 0.191$ & $0.275 \pm 0.133$ & $0.185 \pm 0.010$ & $0.130 \pm 0.047$ & $0.233^{\mathrm{d}}$ \\
\hline 1 & $0.745 \pm 0.184$ & $0.305 \pm 0.068$ & $0.430 \pm 0.028$ & $0.150 \pm 0.050$ & $0.407^{\mathrm{c}}$ \\
\hline 1.5 & $1.265 \pm 0.491$ & $1.255 \pm 0.211$ & $0.490 \pm 0.148$ & $0.055 \pm 0.001$ & $0.766^{\mathrm{a}}$ \\
\hline \multirow[t]{2}{*}{2} & $1.245 \pm 0.088$ & $0.880 \pm 0.136$ & $0.145 \pm 0.019$ & $0.135 \pm 0.074$ & $0.601^{\mathrm{b}}$ \\
\hline & $0.900^{\mathrm{a}}$ & $0.678^{\mathrm{b}}$ & $0.312^{\mathrm{c}}$ & $0.118^{\mathrm{d}}$ & \\
\hline
\end{tabular}

PGR = Plant Growth Regulation, WAP $=$ Weeks After Planting

Different superscript within the same row and column shows significant $(\mathrm{P}<0.05)$ difference 
The lowest of callus height growth in first week after planting occurred in all PGR concentrations of 2,4-D. Type of pre-globular embryo that is equal to 0 $\mathrm{cm}$ and the highest occurred in PGR concentration of 2,4-D $1.5 \mathrm{mg} / \mathrm{L}$ in type of mature embryo that is equal to $1,085 \mathrm{~cm}$. Results of analysis of variance showed PGR giving 2,4-D at all levels of concentration and type of embryos significantly different with high accretion callus $(\mathrm{P}<0.05)$. Interaction between PGR giving 2,4-D and high-gain types of embryo against callus. The pattern of high accretion callus from the first week to the fourth week after planting that is contained in the delivery of PGR maximum peak of 2,4-D $1.5 \mathrm{mg} / \mathrm{L}$ while the minimum peak occurs at $0.5 \mathrm{mg} / \mathrm{L}$. Type of embryos that showed the best performance on high accretion callus every week observation is mature embryos. A similar incident occurred in the fourth week after planting there is high accretion lowest callus persists on the type of pre-globular embryo of $0.055 \mathrm{~cm}$ while the highest occurred in PGR concentrations of 2,4-D $1.5 \mathrm{mg} / \mathrm{L}$ in type of mature embryo of $1.265 \mathrm{~cm}$.

Growth in mature embryos showed better results compared with other types of embryos. The influence of this difference is due to the superiority of the embryo is already ripe. Sources of nutrients from embryos that are ripe will bring good nutrition to the embryo than other types of embryos is not yet complete so that the process will be slower compared to embryos that had matured. Arsyad (2013) states that the mature zygotic embryos have a regenerative capability better than the old embryo or embryos are too young. These results are consistent with research Mirici et al. (2009) showed that mature zygotic embryo has the activity of cell division, growth and the ability regeneratf organelles were high compared to the older embryos. The content of endogenous or exogenous hormones affect plant regeneration was lamtoro. These results are consistent with studies showing that high performance best callus occur in the plant growth regulator auxin 2,4-D 1.5 $\mathrm{mg} / \mathrm{L}$. Uranbey (2011) states that the appropriate use of embryos as explants will increase the amount of callus produced plantlets along with the use of endogenous or exogenous hormone auxin (IAA). Therefore, the use of mature embryo at a concentration of plant growth regulator auxin 2,4-D $1.5 \mathrm{mg} / \mathrm{L}$ is an appropriate alternative.

Effect of 2,4-D and type embryo embryogenic callus diameter ratio is the result of a reaction to exogenous auxin uptake activity were given. These results are consistent with Sari et al. (2014) research which states that the absorption of exogenous and endogenous auxin will cause cell division continuously increasing the number of cell tissue. Diameter growth lamtoro callus
(L. leucocephala cv. Tarramba) are presented in Table 2.

The lowest of diameter growth in the first week after planting occurred in all PGR concentrations of 2,4-D. The type of pre-globular embryo that is equal to $0 \mathrm{~cm}$ and the highest occurred in PGR concentration of 2,4-D $1.5 \mathrm{mg} / \mathrm{L}$ in type of mature embryo that is equal to $1.460 \mathrm{~cm}$. Results of analysis of variance showed PGR giving 2,4-D at all levels of concentration and types of different embryonic callus significantly on the increase in diameter $(\mathrm{P}<0.05)$. Interaction between PGR giving 2,4-D and type embryos to increase the diameter of the callus. The pattern of the increase in diameter of callus from the first week to the fourth week after planting that is contained in the delivery of PGR maximum peak of 2,4-D $1.5 \mathrm{mg} / \mathrm{L}$ while the minimum peak occurs at $0.5 \mathrm{mg} / \mathrm{L}$. type of embryos that showed the best performance on high accretion callus every week observation is mature embryos. A similar incident occurred in the fourth week after planting there is high accretion lowest callus persists on the type of preglobular embryos is $0.222 \mathrm{~cm}$ while the highest occurred in PGR concentration of 2,4-D $1.5 \mathrm{mg} / \mathrm{L}$ in type of mature embryo is $1.330 \mathrm{~cm}$.

Callus diameter growth is the influence of PGR provision of 2,4-D that has no interaction on the type of embryo. Callus diameter accretion process described in the study of Sari et al. (2014) that the use of 2,4-D PGR influence on callus diameter. Auxin absorption will cause cell division continuously increasing the number of cells. In general, the four types of embryo provide developmental responses in diameter, but the speed and regeneration of the cells are different.

Rahmawati (2016) is stated that dosing PGR 2,4-D $1 \mathrm{mg} / \mathrm{L}$ shows the effect of the growth and development of plant callus lamtoro Tarramba best cultivars. The study is in line with the results of this research are giving PGR best 2.4 occurred at a dose of $1.5 \mathrm{mg} / \mathrm{L}$, so that there is an increase in dose to grow new ones. Callus diameter growth is presented in Figure 1.

Figure 1 shows the linear relationship and interaction between the type of embryo and plant growth regulator concentration of 2,4-D to increase callus diameter $\left(\mathrm{cm}^{-1}\right)$. Callus diameter growth every week on PGR concentration of 2,4-D $1.5 \mathrm{mg} / \mathrm{L}$ relatively high compared with 2,4-D PGR $2 \mathrm{mg} / \mathrm{L}, 1$ $\mathrm{mg} / \mathrm{L}$, and $0.5 \mathrm{mg} / \mathrm{L}$. Type embryos showed the best performance based on the increase in diameter respectively callus is mature embryo, cotyledon, heart, and pre-globular. Figure 1 shows the same pattern every week callus growth slowdown that occurred in the third week after planting up to four weeks after planting, this means that in the third week after planting an optimum peak PGR callus growth on medium with 2,4-D. 
Manpaki et al. Growth response of leucaena embryogenic callus on embryo age differences and Auxin 2,4-Dichlorophenoxyacetic acid

Table 2. Diameter growth of embryogenic callus (L. leucocephala cv. Tarramba)

\begin{tabular}{|c|c|c|c|c|c|}
\hline \multirow{3}{*}{ PGR dose 2,4-D (mg/L) } & \multicolumn{4}{|c|}{ Embryo types } & \\
\hline & Mature embryo & Cotyledon & Heart & Pre-globular & \\
\hline & \multicolumn{5}{|c|}{ 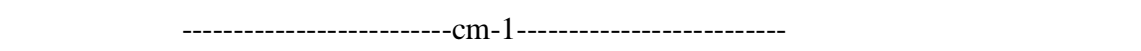 } \\
\hline \multicolumn{6}{|l|}{$1 \mathrm{WAP}$} \\
\hline 0.5 & $0.485 \pm 0.111$ & $0.220 \pm 0.014$ & $0.090 \pm 0.005$ & $0.000 \pm 0.000$ & $0.198^{c}$ \\
\hline 1 & $0.395 \pm 0.010$ & $0.145 \pm 0.082$ & $0.235 \pm 0.095$ & $0.000 \pm 0.000$ & $0.193^{\mathrm{c}}$ \\
\hline 1.5 & $1.460 \pm 0.195$ & $0.580 \pm 0.032$ & $0.605 \pm 0.163$ & $0.000 \pm 0.000$ & $0.661^{\mathrm{a}}$ \\
\hline \multirow[t]{2}{*}{2} & $0.945 \pm 0.060$ & $0.430 \pm 0.013$ & $0.500 \pm 0.015$ & $0.000 \pm 0.000$ & $0.468^{\mathrm{b}}$ \\
\hline & $0.821^{\mathrm{a}}$ & $0.343^{\mathrm{b}}$ & $0.357^{\mathrm{b}}$ & $0.000^{\mathrm{c}}$ & \\
\hline \multicolumn{6}{|l|}{$2 \mathrm{WAP}$} \\
\hline 0.5 & $0.685 \pm 0.013$ & $0.615 \pm 0.023$ & $0.345 \pm 0.051$ & $0.000 \pm 0.000$ & $0.411^{\mathrm{d}}$ \\
\hline 1 & $0.520 \pm 0.105$ & $0.415 \pm 0.130$ & $0.375 \pm 0.011$ & $0.000 \pm 0.000$ & $0.327^{\mathrm{c}}$ \\
\hline 1.5 & $3.285 \pm 0.225$ & $1.220 \pm 0.514$ & $0.670 \pm 0.020$ & $0.000 \pm 0.000$ & $1.293^{\mathrm{a}}$ \\
\hline \multirow[t]{2}{*}{2} & $2.435 \pm 0.108$ & $0.760 \pm 0.150$ & $0.670 \pm 0.022$ & $0.000 \pm 0.000$ & $0.966^{\mathrm{b}}$ \\
\hline & $1.731^{\mathrm{a}}$ & $0.752^{\mathrm{b}}$ & $0.515^{\mathrm{c}}$ & $0.000^{\mathrm{d}}$ & \\
\hline \multicolumn{6}{|l|}{3 WAP } \\
\hline 0.5 & $1.060 \pm 0.476$ & $0.955 \pm 0.029$ & $0.515 \pm 0.071$ & $0.000 \pm 0.000$ & $0.633^{\mathrm{d}}$ \\
\hline 1 & $1.160 \pm 0.296$ & $1.090 \pm 0.107$ & $0.600 \pm 0.091$ & $0.000 \pm 0.000$ & $0.712^{\mathrm{c}}$ \\
\hline 1.5 & $3.685 \pm 0.225$ & $2.220 \pm 0.048$ & $0.720 \pm 0.015$ & $0.000 \pm 0.000$ & $1.656^{\mathrm{a}}$ \\
\hline \multirow[t]{2}{*}{2} & $3.085 \pm 0.153$ & $1.515 \pm 0.074$ & $0.685 \pm 0.036$ & $0.000 \pm 0.000$ & $1.321^{\mathrm{b}}$ \\
\hline & $2.247^{\mathrm{a}}$ & $1.445^{\mathrm{b}}$ & $0.630^{c}$ & $0.000^{\mathrm{d}}$ & \\
\hline \multicolumn{6}{|l|}{4 WAP } \\
\hline 0.5 & $0.450 \pm 0.211$ & $1.085 \pm 0.140$ & $0.605 \pm 0.051$ & $0.225 \pm 0.055$ & $0.591^{b}$ \\
\hline 1 & $0.925 \pm 0.190$ & $1.030 \pm 0.097$ & $0.720 \pm 0.040$ & $0.230 \pm 0.047$ & $0.726^{\mathrm{a}}$ \\
\hline 1.5 & $1.330 \pm 0.065$ & $0.640 \pm 0.019$ & $0.730 \pm 0.023$ & $0.240 \pm 0.066$ & $0.735^{\mathrm{a}}$ \\
\hline \multirow[t]{2}{*}{2} & $0.935 \pm 0.142$ & $0.480 \pm 0.069$ & $0.800 \pm 0.040$ & $0.222 \pm 0.041$ & $0.609^{\mathrm{b}}$ \\
\hline & $0.910^{\mathrm{a}}$ & $0.808^{\mathrm{b}}$ & $0.713^{\mathrm{c}}$ & $0.229^{\mathrm{d}}$ & \\
\hline
\end{tabular}

PGR $=$ Plant Growth Regulation

WAP $=$ Weeks After Planting

Different superscript within the same row and column shows significant $(\mathrm{P}<0.05)$ difference

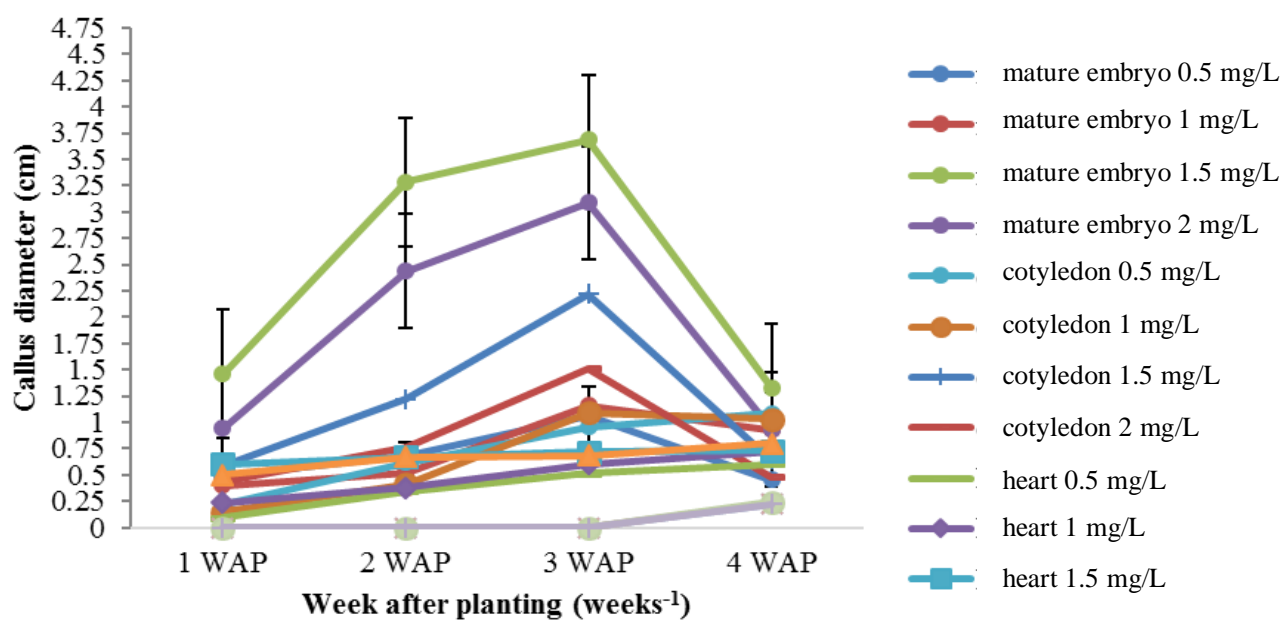

Figure 1. Callus diameter growth of lamtoro (L. leucocephala cv. Tarramba). 


\section{Color and callus texture morphology of Leucaena (L. leucocephala cv. Tarramba)}

Callus color is one of the variables of the morphological characteristics of the most visible callus, while the texture of the callus callus conveniently indicates the ability to regenerate. More and crumb texture of the callus regeneration ability, the better. Callus color of lamtoro (L. leucocephala cv. Tarramba) are presented in Table 3.

Leaf color change in the concentration of 2,4-D PGR against this type of embryos having the same mean score on mature embryo, cotyledon, and a heart that is with a score of 4 (green), while on the type of pre-globular embryos has mean score of 1.80 (tawny). Analysis of variance results showed that administration of 2,4-D PGR concentrations on callus morphology were not significantly different colors while the color types of the morphology of embryos callus was significantly different $(\mathrm{P}<0.05)$.

There are very significant differences between mature embryo, cotyledon, heart, and pre-globular embryos. Colors on mature embryo, cotyledon, and heart has a score of 4 on 1 WAP to 4 WAP there is green, while the pre-globular embryo has a score of 1.7 to 1.9 that is yellow. Arsyad et al. (2013) states that the callus color difference caused by the accumulation of phenolic compounds. Embryos subjected to browning occurs in the regeneration inhibition compared with embryos that do not undergo browning. Callus conveniently indicates normal generally yellow-green to green (Figure 2). Rahmawati (2016) adds that browncolored callus indicates the influence of PGR toxicity of 2,4-D that causes brown colored callus. In addition, the explants were too young to be quickly issued a phenolic compound compared with mature explants. Based on research Moallem et al. (2013) in the early phase of callus induction, the explants browning around the polyphenol oxidation reaction that occurs in the area of injury explants react with the media. The compound will inhibit the growth of plant tissue and cause the plant to die.

Table 3. Morphology of embryogenic lamtoro callus colour (L. leucocephala cv. Tarramba)

\begin{tabular}{lccccc}
\hline \hline & \multicolumn{5}{c}{ PGR $(\mathrm{mg} \mathrm{L})$} \\
\cline { 2 - 6 } Embryo types & 0.5 & 1 & 1.5 & 2 \\
\hline Mature embryo & $4.00 \pm 0.00$ & $4.00 \pm 0.00$ & $4.00 \pm 0.00$ & $4.00 \pm 0.00$ & $4.00^{\mathrm{a}}$ \\
Cotyledon & $4.00 \pm 0.00$ & $4.00 \pm 0.00$ & $4.00 \pm 0.00$ & $4.00 \pm 0.00$ & $4.00^{\mathrm{a}}$ \\
Heart & $4.00 \pm 0.00$ & $4.00 \pm 0.00$ & $4.00 \pm 0.00$ & $4.00 \pm 0.00$ & $4.00^{\mathrm{a}}$ \\
Pre-globular & $1.95 \pm 0.82$ & $1.70 \pm 0.47$ & $1.75 \pm 0.43$ & $1.80 \pm 0.41$ & $1.80^{\mathrm{b}}$ \\
& 3.48 & 3.42 & 3.43 & 3.45 & \\
\hline
\end{tabular}

PGR $=$ Plant growth regulation

Leaf colour chart $=6$ (yellow); 5 (dark green); 4 (green); 3 (light green); 2 (greenish white); 1 (white)

Different superscript within the same row and column shows significant $(\mathrm{P}<0.05)$ difference
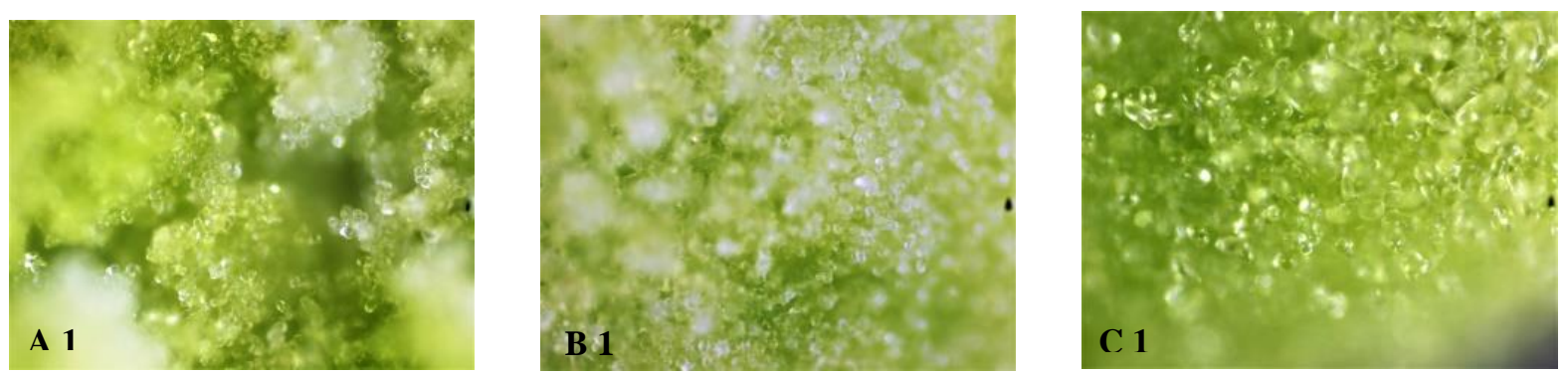

Figure 2. Morphology of embryogenic lamtoro callus (L. leucocephala var. Tarramba) with PGR 2,4-D 1.5 mg/L doses using 100x zooms. (A1) Mature embryo, (B1) Cotyledon, (C1) Heart. 
Manpaki et al. Growth response of leucaena embryogenic callus on embryo age differences and Auxin 2,4-Dichlorophenoxyacetic acid

Table 4. Morphology of embryogenic lamtoro callus texture (L. leucocephala cv. Tarramba)

\begin{tabular}{lcccc}
\hline \multirow{2}{*}{ Embryo types } & \multicolumn{4}{c}{ PGR $(\mathrm{mg} / \mathrm{L})$} \\
\cline { 2 - 4 } & 0.5 & 1 & 1.5 & 2 \\
\hline Mature embryo & $4.00 \pm 0.00$ & $4.00 \pm 0.00$ & $4.00 \pm 0.00$ & $4.00 \pm 0.00$ \\
Cotyledon & $4.00 \pm 0.00$ & $4.00 \pm 0.00$ & $4.00 \pm 0.00$ & $4.00 \pm 0.00$ \\
Heart & $4.00 \pm 0.00$ & $4.00 \pm 0.00$ & $4.00 \pm 0.00$ & $4.00 \pm 0.00$ \\
Pre-globular & $4.00 \pm 0.00$ & $4.00 \pm 0.00$ & $4.00 \pm 0.00$ & $4.00 \pm 0.00$ \\
\hline
\end{tabular}

PGR = Plant Growth Regulation

Callus texture score = very compact (5); compact (4); crumb (3); very crumb (2)

Different superscript within the same row and column shows significant $(\mathrm{P}<0.05)$ difference

Callus texture consists of a compact type of texture and crumb texture. Compact texture has a cell structure that is solid, tied to each other, and gather, while the texture of the crumb has a rare cell structure, hollow, dispersed, and has a crumb spot. Changes of callus texture on the entire PGR concentrations of 2,4-D and type embryos have the same texture is compact. Good callus crumb texture to make it easier to regenerate into plants. Crumb callus morphological characteristics indicate that the cells have properties for producing many embryos embryogenic somatic and easy to divide in plant regeneration. The morphology of the callus texture (L. leucocephala cv. Tarramba) are presented in Table 4Callus crusts are composed of cells with sufficient space and cavity width. Rahmawati (2016) suggests that the interaction between the cotyledons explants types of plants and plant growth regulator 2,4D $1 \mathrm{mg} / \mathrm{L}$ shows the morphological characteristics of most well after gamma-ray irradiation. Based on Hopkins (2010) research, the use of high auxin dose levels would cause infected cells, enlarged, and undergo rapid cell division is not normal. The statement is in accordance with the findings that there is callus which has a superior texture morphology at doses of 2,4-D PGR $2 \mathrm{mg} / \mathrm{L}$.

\section{CONCLUSION}

Embryogenic callus growth response and lamtoro morphology (L. leucocephala cv. Tarramba) is optimal in $1.5 \mathrm{mg} / \mathrm{L}$ of $2,4-\mathrm{D}$ PGR concentration. based on the embryo used, mature embryo shows the most optimal manner of morphophysiology. Embryogenic callus such as mature embryo, cotyledon, and heart showed a faster growth rate than pre-globular embryos. There is no interaction between the administration of PGR concentration of 2,4-D and type embryos.

\section{ACKNOWLEDGEMENT}

Authors wish to thank "Prime Research according to the mandate Division" directorate general of higher education 2015 for financial support.

\section{REFERENCES}

Arsyad MA, Sudarsono, Purwito A, Dinarty D. 2013. Pengaruh umur embrio dan jenis media dasar terhadap keberhasilan embryo rescue aren (Arenga pinnata (wurmb) merr.) secara in vitro. Buletin Palma. 14:2027.

Binott JJ, Songa JM, Ininda I, Njagi EM, Machuka J. 2008. Plant regeneration from immature embryos of Kenyan maize inbred lines and their respective single cross hybrids through somatic embryogenesis. Afr J Biotechnol. 7:981-987.

Hopkins WG. 2010. Plant biotechnology. Philadelphia (USA): Chelsea House.

Manpaki SJ, Karti PDM, Prihantoro I. 2016. Respon pertumbuhan eksplan tanaman lamtoro (Leucaena leucocephala cv. teramba) terhadap cekaman kemasaman media dengan level pemberian aluminium melalui kultur jaringan. Jurnal Sain Peternakan Indonesia. 12:71-82.

Mirici S, Parmaksiz I, Ozcan S, Sancak C, Uranbey S,.Sarihan EO, Gumuscu A, Gurbuz B, Arslan. 2009. Efficient in vitro bulblet regeneration from immature embryos of endangered Sternbergia fischeriana. Plant Cell Tissue Organ Cult. 80:239-246.

Moallem S, Behbahani M, Mousavi S. 2013. Effect of gamma radiation on callus induction and regeneration of Rosa canina through in vitro culture. Trakia J Sci. 11:158162.

Rahmawati L. 2016. Optimasi produksi kalus lamtoro (Leucaena leucocephala) cv. Tarramba dan karakteristik pertumbuhannya akibat iradiasi sinar gamma. (Dissertation). [Bogor (Indones)]: Bogor Agricultural University. 
Sari L, Purwito A, Sopandie D, Purnamaningsih R, Sudarmonowati E. 2014. Wheat (Triticum aestivum L.) mutants throught in vitro selection tolerant on lowland tropic. Intern J Agron Agric Res. 5:189-199.

Uranbey. 2011. In vitro bulblet regeneration from immature embryos of endangered and Endemic Muscari azureum. Arch Biol Sci. 63:209-215.
Yumiarty H, Suradi K. 2010. Utilization of lamtoro leaf in diet on pet production and the lose of hair rabbit's pelt. $\mathrm{J}$ Ilmu Ternak. 7:73-77.

Zayed MZ, Ahmad FB, Zaki MA, Ho WS, Pang SL. 2014. The reduction of mimosine content in Leucaena leucocephala (petai belalang) leaves using Ethyl Methane Sulphonate (EMS). Arch Appl Sci Res. 6:124128. 